\title{
Yield Loss Assessment in Bread Wheat Varieties Caused by Yellow Rust (Puccinia striiformis f. sp. tritici) in Arsi Highlands of South Eastern Ethiopia
}

\author{
Alemu Ayele, Getnet Muche \\ Ethiopian Institute of Agricultural Research (EIAR), Kulumsa Agricultural Research Center, Asella, Ethiopia \\ Email address: \\ alemuayele81@gmail.com (A. Ayele),getnetmuche2014@gmail.com(G. Muche) \\ To cite this article: \\ Alemu Ayele, Getnet Muche. Yield Loss Assessment in Bread Wheat Varieties Caused by Yellow Rust (Puccinia striiformis f. sp. tritici) in \\ Arsi Highlands of South Eastern Ethiopia. American Journal of BioScience. Vol. 7, No. 6, 2019, pp. 104-112. \\ doi: 10.11648/j.ajbio.20190706.14
}

Received: October 8, 2019; Accepted: November 26, 2019; Published: December 6, 2019

\begin{abstract}
Wheat yellow rust disease caused by Puccinia striiformis f. sp. tritici is one of the most feared and wheat production bottlenecks in the highland areas of Ethiopia. Field experiment was conducted to assess wheat yield losses caused by Puccinia striiformis f. sp. tritici based at optimal frequency of fungicide with wheat varieties for the control of stripe rust at hotspot environments of Meraro and Bekoji, experimental stations in Arsi zone in 2017 main cropping season. Results revealed that there was direct linkage between the disease level and the yield loss in the most common commercially adopted bread wheat varieties. There was varying resistance level among different wheat varieties. The extensively cultivated wheat variety, Wane was found to be most resistant with minimum yield loss of 22.9 to $39.7 \%$ followed by Lemu and Danda'a with yield loss of 48.7 to $56.5 \%$ and 43.3 to $57.5 \%$ at Bekoji and Meraro respectively. While Kubsa, proved to be the most susceptible wheat variety with maximum yield loss of 91.5 to $96.7 \%$ at Bekoji and Meraro respectively. Therefore, it is advisable to use resistant varieties with appropriate fungicides with optimal frequency in order to reduce yield loss and get comparable yield advantage by reducing the incurring of wheat stripe rust in wheat farms.
\end{abstract}

Keywords: Bread Wheat, Yellow Rust, Puccinia Striiformis, Yield Loss

\section{Introduction}

Stripe rust of wheat is one of the most important fungal diseases of wheat and the major production bottleneck in the major wheat producing regions of Ethiopia [1] Arsi and Bale regions of the country are the known hotspots for the epidemics of stripe rust of wheat [2] Even though there is seasonal variability in the occurrence of stripe rust in Arsi and Bale highlands, the main and long rainy season is ideal for stripe rust development [3].

Yellow rust can cause yield losses of up to $58 \%$ on susceptible cultivars if infection occurs very early in the crop development stage and the disease continues to develop during the growing season [4]. Grain yield loss of $71 \%$ has been recorded on susceptible bread wheat variety Wabe in Bale [5]. Stripe rust also reduced the germination ability and kernel weight of Dashen by 72 and $56 \%$ respectively [4].

Foliar fungicides were applied at different stages of a stripe rust epidemic, nil disease, trace of disease or moderate disease, on wheat cultivars which differed in susceptibility to the disease. The fungicides were also measured disease severity and host reaction. The mean area under the disease progress curve (AUPDC) of flag leaves of the susceptible cultivar was reduced by $65 \%$ and for the moderately susceptible cultivar was reduced by $41-50 \%$ after the application of the fungicides respectively [6]. The more resistant cultivars had very low AUDPCs and would probably not benefit from an application of fungicide to control stripe rust, unless the pathotype present was highly virulent against these cultivars [7]. Fungicide tests in Kenya showed $50 \%$ higher yield in the treated versus the untreated plots [8]. Timely application of fungicides effectively prevented yield losses and further spread of the disease to the wheat production regions, and potentially huge nationwide yield loss was avoided through use of fungicides [9]. The use of chemicals had helped in significantly reducing crop loss 
during the 2010 yellow rust epidemic [2]. All the current commercial wheat cultivars in East Africa are susceptible to the new race and it is not possible to grow a profitable crop of wheat without the application of fungicides [8]. Due to variable environmental conditions and new race formation much of studies focus on fungicide efficacies and yield losses of susceptible cultivars, but yield losses and fungicide frequencies with response to bread wheat varieties are yet studied. Hence, the present investigation was carried out to study yield losses caused by stripe rust disease in relation to bread wheat varieties.

\section{Materials and Methods}

The Field experiment was undertaken under two rain fed Kulumsa Agricultural Research Center sub-stations, Bekoji and Meraro in Arsi highlands of South Western Ethiopia during 2017 main cropping season.

\subsection{Description of Study Sites}

Bekoji substation is located at $07^{\circ} 32^{\prime} 37^{\prime \prime} \mathrm{N}, 39^{\circ} 15^{\prime} 21^{\prime \prime E}$ and at 2780 meters above sea level (m. a. sl). It receives mean annual rainfall of $1020 \mathrm{~mm}$ representing highland \& high rainfall agro ecology. The monthly mean minimum and maximum temperature is 7.9 and $18.6{ }^{\circ} \mathrm{C}$, respectively. The dominant soil type is Clay soil (Nitosols) which is slightly acidic (Soil $\mathrm{pH}=5.0$ ). Meraro substation is located at $07^{\circ} 24^{\prime}$ $27^{\prime \prime} \mathrm{N}, 39^{\circ} 14^{\prime} 56^{\prime \prime} \mathrm{E}$ and 2990 masl. Its average annual rainfall is $1196 \mathrm{~mm}$ representing extreme highland \& frost prone agro ecology. The minimum and maximum temperature is 5.7 and $18.1^{\circ} \mathrm{C}$, respectively. The dominant soil type is Clay soil (Nitosols) which is similar as Bekoji's soil type [10]. Both locations represent major wheat-growing and yellow rust prone areas in the highlands of Arsi. They are also characterized by bimodal rainfall, the short rainy season extending from March to May and the main rainy season from June to September.

\subsection{Treatments and Experimental Design}

The experiment was laid out in randomized complete block design (RCBD) in factorial arrangement with three replications. Four bread wheat varieties, released from Kulumsa Agricultural Research Center KARC namely Kubsa, Wane, Danda'a and Lemmu, were used. These varieties were selected based on their response to stripe rust with Kubsa being susceptible, Danda moderately susceptible, Lemmu moderately resistant and Wane resistant respectively. Wheat varieties were planted at the recommended rate of 150 $\mathrm{kg}$ seed ha-1 to six rowed plots of $2.5 \mathrm{~m}$ length and $1.2 \mathrm{~m}$ width with $20 \mathrm{~cm}$ inter-row spacing. The gaps between plots and replications were $1 \mathrm{~m}$ and $1.5 \mathrm{~m}$, respectively. Spreader rows (Highly susceptible varieties) consisting of a mixture of different susceptible bread wheat varieties were bordered in each rows in order to ensure uniform spread of inoculums and sufficient disease development.

Wheat plots were sprayed with recently registered and widely used fungicides viz. Rex ${ }^{\circledR}$ Duo (Epoxiconazole + Thiophanate-methyl) and Tilt 250EC*(propiconazole) at 0.5 $\mathrm{L}$ product ha- ${ }^{1}$ to maintain disease free wheat plants enabling us to compare wheat yield in diseased and disease free experimental units.

Table 1. Fungicides used in trials to bread wheat varieties.

\begin{tabular}{llll}
\hline Common name & Trade name & Active ingredient & Application rate (litres ha $\left.^{-1}\right)$ \\
\hline Propiconazole & Tilt & $25 \mathrm{EC}$ at $0.1 \%$ con. & 0.5 \\
Epoxiconazole + Thiophanate-methyl & $\operatorname{Rex}^{\circledR}$ Duo & Epoqsikonazol $(187 \mathrm{~g} / \mathrm{l})$, thiofan methyl $(310 \mathrm{~g} / \mathrm{l})$ & 0.5 \\
\hline
\end{tabular}

The fungicides were applied three times including Control $(0+2)$ with an interval of 15 days starting from disease appearance when spreader varieties were reached 20 percent disease severity. Treated plots were applied with frequently sprays of once and twice in which the sprays were done first and 16 days, respectively after the appearance of stripe rust symptoms. During fungicide sprays, plastic sheets were used to separate the plot being sprayed from the adjacent plots and unsprayed plots, of each variety were also included. The effect of fungicide sprayed at different disease levels, plant reached to maturity was also studied. Observations on yellow rust severity were estimated according to modified Cobb's scale [11]. Recommended rate of fertilizer $\left(41 \mathrm{~kg} \mathrm{ha}^{-1} \mathrm{~N}\right.$ and $46 \mathrm{~kg} \mathrm{ha}^{-1} \mathrm{P}_{2} \mathrm{O}_{5}$ ) was applied during planting time. Proper fertilizer application and control of insect-pests, and weeds were controlled three times by hand weeding.

\subsection{Data Collected}

Data was recorded on plot and single plant basis in which plot basis data was taken from the central four rows $\left(2 \mathrm{~m}^{2}\right.$ net areas) of the plot. On the other hand, individual plant based data was also taken from ten plants in each plot taken randomly from the central four rows of each plot, and means of the 10 plants were used for data analyses. Yellow rust severity, estimated as proportion of the tissues of a plant affected by the disease, was recorded four times at 15 days interval from the stripe rust levels on spreaders rows of Morocco reached $20 \%$ severity of symptom appearance to physiological maturity of the crop, using the modified Cobb's scale (Peterson et al., 1948) which was used to determine the percentage of possible tissue rusted and evaluated from $1 \%$ to $100 \%$, by assessing 10 randomly pre-tagged plants, and the response of individual plants were recorded. During disease assessment, the growth stage of the crop was recorded to observe onset and progress of the disease in relation to wheat phenology. Crop growth stage was assessed based on the decimalized key developed by [12].

Disease severity: Relative or absolute area of plant tissue affected by disease in relation to the total area. 
Disease Severity $=\frac{\text { Area of plant tissue infected }}{\text { Total area of the plant part examined }}$
The percent rust severity control was calculated by the following formula:

$$
\text { Percent Disease Contrlo }=\left(\frac{\text { Percent Severity intreated plot-percent severity in untreated plot }}{\text { percent severity in untreated check }}\right) \times 100
$$

Disease incidences: Proportion of plants (or plant units), the number of diseases out of N-plants (or plant units observed).

$$
\text { Disease incidence }=\frac{\text { No.of diseased plants }}{\text { Total No.of plants examined }} \times 100
$$

The final disease severity data for the stripe rust was converted into a coefficient of infection (CI) by multiplying severity with a constant value for field response [13-15]. The area under disease progress curve (AUDPC) was calculated for individual plants using the CI values from the original rust severity data by using the following formula as suggested by [16].

$$
\text { AUDPC }=\sum_{i=1}^{n-1} 0.5(x i+1+x i)(t i+1-t i)
$$

where, $x i=$ the average coefficient of infection of ith record, $\mathrm{Xi}+1=$ the average coefficient of infection of $\mathrm{i}+1$ th record and $\mathrm{t} \mathrm{i}+1-\mathrm{t}=$ Number of days between the ith record and $\mathrm{i}+1$ th record, and $n=$ number of observations. The minimum and maximum limits of AUDPC were 1 to 199, 200 to 399,400 to 599 and 600 to soon, which were categorized under resistant (R), moderately resistant (MR), (MS) to susceptible (S) respectively. Yield and yield related components were recorded on the middle four rows of each experimental unit.

Number of grains per spike (NG): The number of grains of the main tillers of each of the ten randomly taken plants for each experimental were recorded and the average of the ten plants will be used for analysis.

Thousand Seed weight (TSW) (g): The weights of thousand seeds were determined by carefully counting the grains, adjusting to $12.5 \%$ moisture content and weighing them using sensitive balance.

Hectolitre weight (HLW) $(\mathrm{g} / \mathrm{hL})$ : - Grain weight of onelitter volume (random sample) was estimated for each experimental unit by following standard procedure [17] and the result will be converted to $\mathrm{g} / \mathrm{hL}$.

Grain yield $(\mathrm{GY})(\mathrm{kg})$ : Grain yield in $\mathrm{g} / \mathrm{plot}$ at $12.5 \%$ moisture content was recorded and converted to $\mathrm{kg} / \mathrm{hectare}$.

\section{Grain yield loss estimation}

The relative losses in yield and yield component of each variety were determined as a percentage of that of the protected plots of the respective variety. Losses were calculated separately for each of the treatments with different levels of disease, as

$$
\mathrm{RL}(\%)=\frac{100((Y 1-Y 2))}{Y 1}
$$

Where, $\mathrm{RL}=$ relative loss (reduction of the parameters grain yield and TKW), Y1=mean of the respective parameter on protected plots (plots with maximum protection) and $\mathrm{Y} 2=$ mean of the respective parameter in unprotected plots (i.e. unsprayed plots or sprayed plots with varying level of disease)

\subsection{Data Analysis}

Data from each of the two locations were subjected to analysis of variance (ANOVA) according to (18) using SAS computer software package version 9.0 [19]. Least Significant Difference (LSD 0.05) values were used to know the significant difference between mean values of the treatments for the character in question. Finally, the data were utilized in selecting the best fungicide and fungicide frequency with the resistant variety that significantly reduces yellow rust disease and results in better yield. Data on yellow rust yield and yield component parameters were correlated using the Proc-Corr Procedures [19].

\section{Result}

\subsection{Grain Yield Loss}

At Bekoji, maximum relative grain yield losses 36\%, and this was recorded on unsprayed plots of variety kubsa and the

\begin{tabular}{|c|c|c|c|c|c|}
\hline \multicolumn{2}{|c|}{ Treatments } & \multirow{2}{*}{$\begin{array}{l}\text { Bekoji } \\
\text { Yield }\end{array}$} & \multicolumn{3}{|c|}{ Meraro } \\
\hline Variety & Fungicide & & Loss (\%) & Yield & Loss (\%) \\
\hline \multirow{5}{*}{ Wane } & Unsprayed & $4688.0^{\mathrm{d}}$ & 22.9 & $2965.0^{\mathrm{f}}$ & 39.7 \\
\hline & Once application of Tilt $250 \mathrm{EC}$ & $4805.0^{\mathrm{cd}}$ & 20.9 & $2978.3^{\mathrm{f}}$ & 39.5 \\
\hline & Twice application of Tilt $250 \mathrm{EC}$ & $5921.7^{\text {ab }}$ & 2.7 & $4651.7^{\mathrm{b}}$ & 5.4 \\
\hline & Once application of Rex ${ }^{\circledR}$ Duo & $5108.3^{c}$ & 16 & $3335.0^{\mathrm{d}}$ & 32.2 \\
\hline & Twice application of Rex® Duo & $6085.0^{\mathrm{a}}$ & 0 & $4920.0^{\mathrm{a}}$ & 0 \\
\hline \multirow{5}{*}{ Lemu } & Unsprayed & $2938.3^{\text {f-h }}$ & 48.7 & $2151.7^{\mathrm{ij}}$ & 56.5 \\
\hline & Once application of Tilt 250 EC & $3048.3^{\mathrm{fg}}$ & 46.8 & $2498.3^{\mathrm{h}}$ & 49.5 \\
\hline & Twice application of Tilt $250 \mathrm{EC}$ & $4545.0^{\mathrm{d}}$ & 20.7 & $3665.0^{c}$ & 25.9 \\
\hline & Once application of Rex ${ }^{\circledR}$ Duo & $4151.7^{\mathrm{e}}$ & 27.5 & $3180.0^{\mathrm{e}}$ & 35.7 \\
\hline & Twice application of Rex® Duo & $5738.3^{\mathrm{b}}$ & 0 & $4943.3^{\mathrm{a}}$ & 0 \\
\hline \multirow{2}{*}{ Dana'a } & Unsprayed & $2638.3^{\mathrm{hi}}$ & 43.3 & $1565.0^{1}$ & 57.5 \\
\hline & Once application of Tilt $250 \mathrm{EC}$ & $2753.3^{\mathrm{g}-\mathrm{i}}$ & 40.8 & $1860.0^{\mathrm{k}}$ & 49.5 \\
\hline
\end{tabular}
comparison of total and percent yield loss due to stripe rust was indicated in (Table 2).

Table 2. Grain yield losses at four bread wheat varieties with different fungicide application frequency at Bekoji and Meraro 2017 main cropping season. 


\begin{tabular}{|c|c|c|c|c|c|}
\hline \multicolumn{2}{|l|}{ Treatments } & \multicolumn{2}{|l|}{ Bekoji } & \multicolumn{2}{|l|}{ Meraro } \\
\hline Variety & Fungicide & Yield & Loss (\%) & Yield & Loss (\%) \\
\hline \multirow{8}{*}{ Kubsa } & Twice application of Tilt $250 \mathrm{EC}$ & $3955.0^{\mathrm{e}}$ & 15 & $2658.3^{g}$ & 27.9 \\
\hline & Once application of Rex ${ }^{\circledR}$ Duo & $2831.7^{\text {gh }}$ & 39.1 & $2160.0^{\mathrm{i}}$ & 41.4 \\
\hline & Twice application of Rex ${ }^{\circledR}$ Duo & $4653.3^{\mathrm{d}}$ & 0 & $3685.0^{\mathrm{c}}$ & 0 \\
\hline & Unsprayed & $273.3^{1}$ & 91.5 & $106.7^{\circ}$ & 96.7 \\
\hline & Once application of Tilt $250 \mathrm{EC}$ & $948.3^{\mathrm{k}}$ & 70.7 & $406.0^{\mathrm{n}}$ & 87.3 \\
\hline & Twice application of Tilt 250 EC & $2521.7^{\mathrm{i}}$ & 21.9 & $2100.0^{\mathrm{j}}$ & 34.2 \\
\hline & Once application of Rex ${ }^{\circledR}$ Duo & $2126.7^{j}$ & 33.5 & $601.0^{\mathrm{m}}$ & 81.1 \\
\hline & Twice application of Rex ${ }^{\circledR}$ Duo & $3240.0^{\mathrm{f}}$ & 0 & $3191.7^{\mathrm{e}}$ & 0 \\
\hline CV\% & & 5.11 & & 1.33 & \\
\hline $\operatorname{LSD}(0.05)$ & & 307.73 & & 58.85 & \\
\hline
\end{tabular}

$\mathrm{LSD}_{0.05}=$ List significant difference at $5 \%, \mathrm{CV}(\%)=$ Coefficient of variation at $(\%)$. Means in same column followed by the same letters are not significantly different. loss $\%=$ yield loss.

\subsection{Thousand Kernel Weight Losses}

Likewise, grain yield losses in TKW due to yellow rust were higher for variety Kubsa than Danda'a (Table 3).

Table 3. Thousand kernel weight losses at four bread wheat varieties with different fungicide application frequency at Bekoji and Meraro 2017 main cropping season.

\begin{tabular}{|c|c|c|c|c|c|}
\hline Treatments & & Bekoji & & Meraro & \\
\hline Variety & Fungicide & TKW & Loss (\%) & TKW & Loss $(\%)$ \\
\hline \multirow{5}{*}{ Wane } & Unsprayed & $27.6^{\mathrm{d}-\mathrm{f}}$ & 17 & $33.7^{\mathrm{i}}$ & 14.3 \\
\hline & Once application of Tilt $250 \mathrm{EC}$ & $30.6^{\mathrm{b}-\mathrm{e}}$ & 8.6 & $33.9^{\text {hi }}$ & 13.7 \\
\hline & Twice application of Tilt $250 \mathrm{EC}$ & $30.2^{\mathrm{b}}-\mathrm{f}$ & 9.8 & $37.8^{\mathrm{fg}}$ & 3.7 \\
\hline & Once application of Rex ${ }^{\circledR}$ Duo & $29.2^{\mathrm{c}-\mathrm{f}}$ & 12.2 & $36.3^{\mathrm{g}}$ & 7.6 \\
\hline & Twice application of Rex® Duo & $33.7^{\mathrm{ab}}$ & 0 & $39.3^{\text {ef }}$ & 0 \\
\hline \multirow{5}{*}{ Lemu } & Unsprayed & $27.9^{\mathrm{d}-\mathrm{f}}$ & 18.7 & $36.2^{\mathrm{gh}}$ & 15.4 \\
\hline & Once application of Tilt $250 \mathrm{EC}$ & $29.6^{\mathrm{c}-\mathrm{f}}$ & 13.9 & $38.0^{\mathrm{fg}}$ & 11.5 \\
\hline & Twice application of Tilt $250 \mathrm{EC}$ & $30.2^{b-f}$ & 12.1 & $40.5^{\mathrm{b}-\mathrm{e}}$ & 5.4 \\
\hline & Once application of Rex® Duo & $32.5^{\mathrm{acc}}$ & 5.6 & $36.9^{\mathrm{g}}$ & 13.8 \\
\hline & Twice application of Rex ${ }^{\circledR}$ Duo & $34.4^{\mathrm{a}}$ & 0 & $42.8^{\mathrm{ab}}$ & 0 \\
\hline \multirow{5}{*}{ Dana'a } & Unsprayed & $26.4^{\mathrm{fg}}$ & 19 & $42.4^{\mathrm{a}-\mathrm{c}}$ & 1.4 \\
\hline & Once application of Tilt $250 \mathrm{EC}$ & $26.9^{\mathrm{ef}}$ & 17.4 & $42.0^{\mathrm{a}-\mathrm{d}}$ & 2.4 \\
\hline & Twice application of Tilt $250 \mathrm{EC}$ & $30.4^{\mathrm{be}}$ & 7.3 & $42.1^{\mathrm{a}-\mathrm{d}}$ & 2 \\
\hline & Once application of Rex ${ }^{\circledR}$ Duo & $27.9^{\mathrm{d}-\mathrm{f}}$ & 14 & $42.5^{\mathrm{a}-\mathrm{c}}$ & 1.2 \\
\hline & Twice application of Rex ${ }^{\circledR}$ Duo & $32.9^{\mathrm{a}-\mathrm{c}}$ & 0 & $43.0^{\mathrm{a}}$ & 0 \\
\hline \multirow{5}{*}{ Kubsa } & Unsprayed & $17.0^{\mathrm{i}}$ & 48.5 & $36.5^{\mathrm{g}}$ & 10.2 \\
\hline & Once application of Tilt $250 \mathrm{EC}$ & $19.5^{\mathrm{hi}}$ & 41.4 & $39.9^{\mathrm{d}-\mathrm{f}}$ & 1.9 \\
\hline & Twice application of Tilt 250 EC & $31.0^{a-d}$ & 7.3 & $40.3^{\mathrm{ce}}$ & 1 \\
\hline & Once application of Rex ${ }^{\circledR}$ Duo & $22.9^{\text {gh }}$ & 31.3 & $39.8^{\text {def }}$ & 2 \\
\hline & Twice application of Rex ${ }^{\circledR}$ Duo & $33.4^{\mathrm{ab}}$ & 0 & $40.5^{\mathrm{a}-\mathrm{e}}$ & 0 \\
\hline $\mathrm{CV} \%$ & & 8.03 & & 3.61 & \\
\hline $\operatorname{LSD}(0.05)$ & & 3.81 & & 2.34 & \\
\hline
\end{tabular}

$\mathrm{LSD}_{0.05}=$ List significant difference at $5 \%, \mathrm{CV}(\%)=$ Coefficient of variation at $(\%)$. Means in same column followed by the same letters are not significantly different. TKW=thousand kernel weight loss $\%=$ thousand kernel weight loss.

\subsection{Hectolitre Weight Loss}

Table 4. Hectolitre weight losses at four bread wheat varieties with different fungicide application frequency at Bekoji and Meraro 2017 main cropping season.

\begin{tabular}{|c|c|c|c|c|c|}
\hline \multicolumn{2}{|c|}{ Treatments } & \multicolumn{2}{|l|}{ Bekoji } & \multicolumn{2}{|c|}{ Meraro } \\
\hline Variety & Fungicide & HLW & Loss $(\%)$ & HLW & Loss (\%) \\
\hline \multirow{5}{*}{ Wane } & Unsprayed & $59.5^{\mathrm{f}-\mathrm{i}}$ & 9.02 & $66.6^{\text {cd }}$ & 9.3 \\
\hline & Once application of Tilt $250 \mathrm{EC}$ & $60.9^{\mathrm{d}-\mathrm{h}}$ & 6.88 & $66.8^{\mathrm{cd}}$ & 9 \\
\hline & Twice application of Tilt $250 \mathrm{EC}$ & $61.9^{\mathrm{c}-\mathrm{g}}$ & 5.35 & $68.0^{c}$ & 7.4 \\
\hline & Once application of Rex ${ }^{\circledR}$ Duo & $60.2^{\mathrm{e}-\mathrm{i}}$ & 7.95 & $68.7^{\mathrm{bc}}$ & 6.4 \\
\hline & Twice application of Rex ${ }^{\circledR}$ Duo & $65.4^{\mathrm{a}-\mathrm{c}}$ & 0 & $73.4^{\mathrm{a}}$ & 0 \\
\hline \multirow{5}{*}{ Lemu } & Unsprayed & $56.4^{\mathrm{ij}}$ & 11.74 & $61.9^{\mathrm{ef}}$ & 13.1 \\
\hline & Once application of Tilt 250 EC & $57.2^{\mathrm{h}-\mathrm{j}}$ & 10.49 & $67.4^{\mathrm{cd}}$ & 5.3 \\
\hline & Twice application of Tilt $250 \mathrm{EC}$ & $62.7^{\mathrm{c}-\mathrm{f}}$ & 1.88 & $71.1^{\mathrm{a}-\mathrm{c}}$ & 0.1 \\
\hline & Once application of Rex ${ }^{\circledR}$ Duo & $60.6^{\mathrm{e}-\mathrm{h}}$ & 5.16 & $67.8^{\mathrm{c}}$ & 4.8 \\
\hline & Twice application of Rex® Duo & $63.9^{\text {b-e }}$ & 0 & $71.2^{\mathrm{a}-\mathrm{c}}$ & 0 \\
\hline \multirow{2}{*}{ Dana'a } & Unsprayed & $43.8^{1}$ & 25.38 & $60.5^{\mathrm{e}-\mathrm{g}}$ & 14.4 \\
\hline & Once application of Tilt $250 \mathrm{EC}$ & $50.1^{\mathrm{k}}$ & 14.65 & $66.6^{\mathrm{cd}}$ & 5.8 \\
\hline
\end{tabular}




\begin{tabular}{llllll}
\hline Treatments & & Bekoji & & Meraro \\
\hline Variety & Fungicide & HLW & Loss (\%) & HLW & Loss (\%) \\
\hline & Twice application of Tilt 250 EC & $55.1^{\mathrm{j}}$ & 6.13 & $67.9^{\mathrm{c}}$ & 4 \\
& Once application of Rex® Duo & $49.5^{\mathrm{k}}$ & 15.67 & $63.2^{\mathrm{de}}$ & 10.6 \\
& Twice application of Rex® Duo & $58.7^{\mathrm{g}-\mathrm{j}}$ & 0 & $70.7^{\mathrm{a}-\mathrm{c}}$ & 0 \\
& Unsprayed & $23.3^{\mathrm{m}}$ & 65.74 & $56.7^{\mathrm{g}}$ & 22.2 \\
& Once application of Tilt 250 EC & $23.3^{\mathrm{m}}$ & 65.74 & $61.7^{\text {ef }}$ & 15.4 \\
Kubsa & Twice application of Tilt 250 EC & $64.5^{\mathrm{a}-\mathrm{d}}$ & 5.15 & $70.9^{\mathrm{a}-\mathrm{c}}$ & 2.7 \\
& Once application of Rex® Duo & $66.5^{\mathrm{ab}}$ & 2.21 & $69.9^{\mathrm{a}-\mathrm{c}}$ & 4.1 \\
& Twice application of Rex® Duo & $68.0^{\mathrm{a}}$ & 0 & $72.9^{\mathrm{ab}}$ & 0 \\
CV\% & & 4.14 & & 4.13 & \\
LSD $(0.05)$ & & 3.79 & & 4.55 & \\
\hline
\end{tabular}

$\mathrm{LSD}_{0.05}=$ List significant difference at $5 \%, \mathrm{CV}(\%)=$ Coefficient of variation at $(\%)$. Means in same column followed by the same letters are not significantly different. HLW=hectoliter weight, Loss $\%=$ hectoliter weight loss in percent.

\subsection{Seed Quality Loss}

The rust pressure also affects the quality of grain due to shriveling of seed. Some damages might have already happened to the sprayed plots as well depending on the timing of spray.
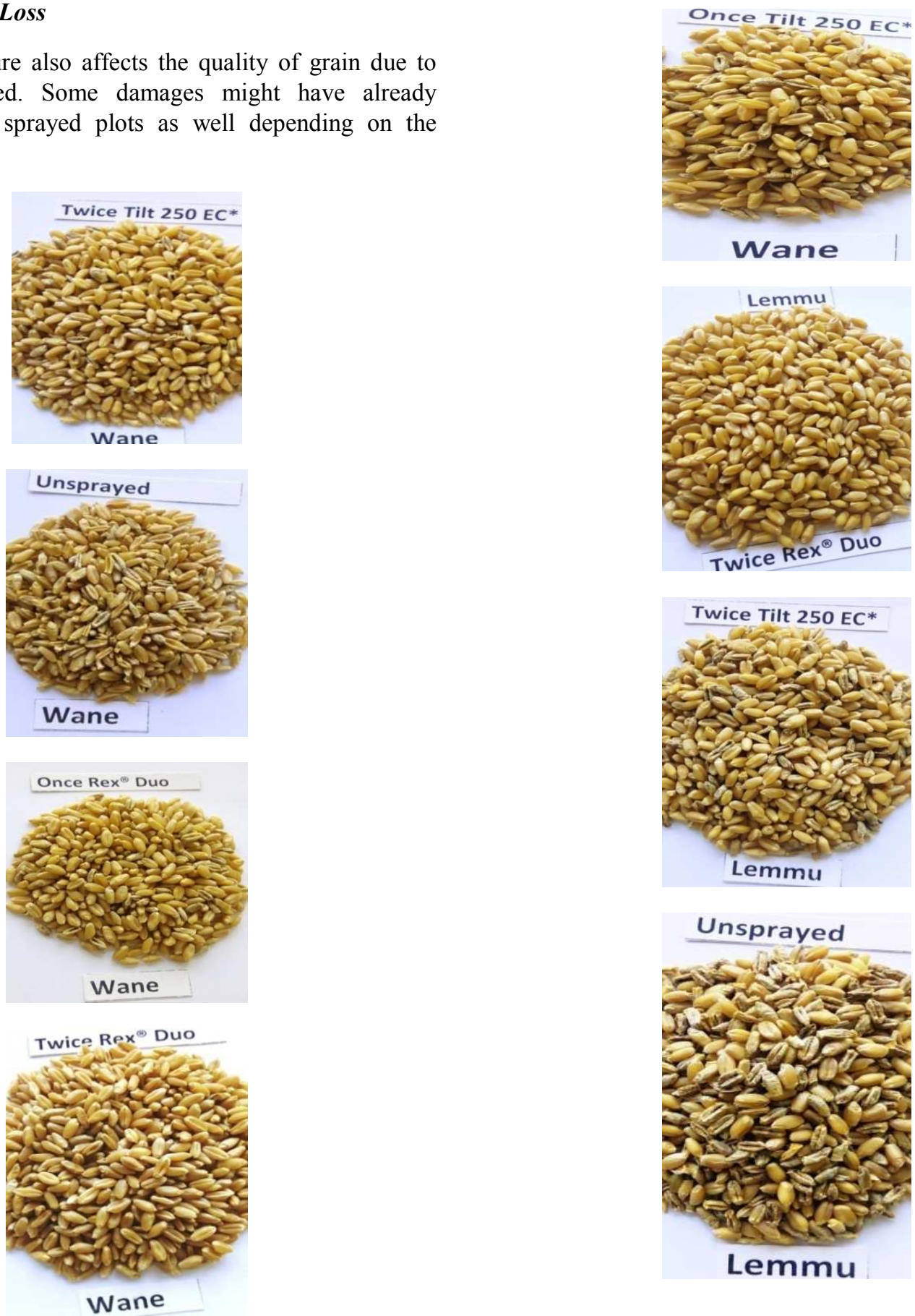

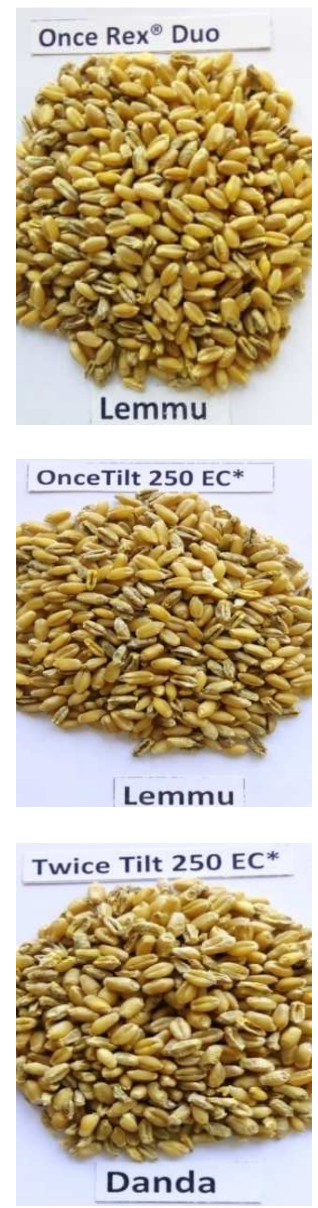

Twice Rex ${ }^{\text {(i) Duo }}$
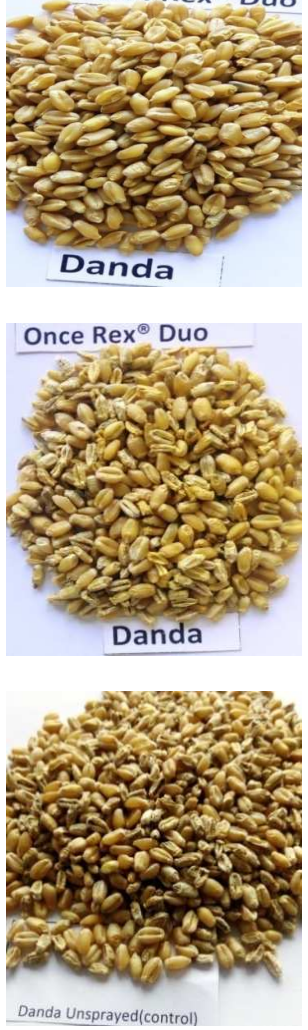
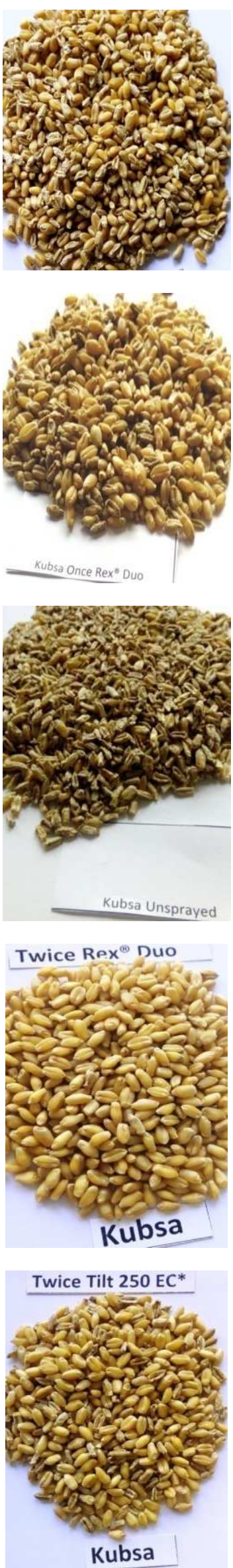


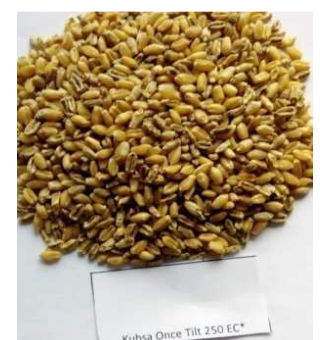

Figure 1. Yellow rust infected and fungicide protected grains of four bread wheat varieties.

\section{Discussion}

It has been found that maximum yield loss of $2967 \mathrm{~kg}$ ha-1 $(92 \%)$ at Bekoji and $3037 \mathrm{~kg} \mathrm{ha}^{-1}(97 \%)$ at Meraro in Kubsa followed by Lemu showing $2800 \mathrm{~kg}$ ha-1 (43\%) at Bekoji and $2791 \mathrm{~kg}$ ha-1 (57\%) loss at Meraro, Danda'a showing $2015 \mathrm{~kg} \mathrm{ha}^{-1}(49 \%)$ at Bekoji and $2120 \mathrm{~kg}$ ha-1 (58\%) loss at Meraro, and Wane showing $1397 \mathrm{~kg} \mathrm{ha}^{-1}(23 \%)$ at Bekoji and $1955 \mathrm{~kg}$ ha-1 (40\%) loss were protected by Twice application frequency of $\operatorname{Rex}{ }^{\circledR}$ Duo over nil fungicide application respectively (table 2). The other Twice application frequency of Tilt $250 \mathrm{EC}^{*}$ protected yield losses to (89 \& 95\%) at kubsa, (33 \& $41 \%)$ at Lemu, (21 \& $36 \%$ ) at Wane, over nil fungicide application at Bekoji and Meraro respectively (Table 2). Though all the wheat varieties belong to the same Triticum aestivum L., species, yet highly significant differences were found among wheat yield as well as disease level.

On Wane, losses in grain yield were generally less than $23 \%$ at Bekoji, comparatively higher severity of yellow rust was recorded (due to the heavy disease pressure), resulting in grain yield loss of up to $40 \%$ at Meraro. Loss in grain yield was generally higher at Meraro than at Bekoji during cropping seasons. In all the varieties, only the twice fungicide application frequency at 15 days interval significantly affected loss of grain yield perhaps, at least partly, due to the staggered start of the sprays after disease appearance. However, the 15 days interval fungicide treatment also significantly increased grain yield of variety Kubsa under high disease pressure at Meraro, suggesting that reduced frequency of fungicide sprays has a potential to control the disease particularly had the first spray been made at disease onset and yield from fungicide sprayed plots were unambiguously higher than unsprayed plots (Table 2). Though all the wheat varieties belong to the same Triticum aestivum L., species, highly significant differences were found among wheat yield as well as disease level (Table 2). The present investigations are in line with the work done by [20] who found that stripe rust cause a $51 \%$ loss in grain yield on the well watered plots from (4.9-2.1 t ha-1) and a $46 \%$ reduction on rain fed plots (2.8-1.5 t ha-1), [21] reported that yield losses increase proportionately with the increase in severity of the disease. According to their investigations, varieties like Kubsa, Danda'a, and Lemu exhibited maximum losses of $43-97 \%$ against of the wheat stripe rust. The present results are agree with findings of [22] in which yellow rust was reported causing grain yield loss of up to $22 \%$. It confirmed that susceptible genotypes showed higher yield losses as compared to resistant genotypes [23]. Yield can be severely reduced if disease pressure is high and yield losses of 30-50\% have been reported in wheat [24-25].

The disease has resulted in TKW loss of up to $49 \%$ that had protected on the variety Kubsa with twice application frequency of Rex ${ }^{\circledR}$ Duo at Bekoji, while maximum loss in TKW of variety Kubsa $67 \%$ was protected at Meraro (Table 3). Varieties might differ in the effect of the disease on other yield components too. However, losses reported by [7] were less than the present studies; they reported 37 percent of thousand kernel weight loss from yellow rust of wheat in highly susceptible lines from Bale highlands. On the other hand, 7\% loss in thousand kernel weigh was recorded on unsprayed variety of Wane, which is considered lowest thousand kernel weight (Table 3). Current results are agreed with previous reports of [26] in which yield, thousand Seed weight hectolitre weight, weight of kernel per spike, losses due to STB were recorded 41, 36 and $44 \%$ respectively. [27] reported up to $45 \%$ reduction in 1000 -kernel weight of wheat variety Oxely in Australia. Of wheat head and leaf sheaths by septoria affects the transport of assimilates to the developing kernel and results in shrivelled [28-29].

Only Rex ${ }^{\circledR}$ Duo fungicide treatment showed significant effect $(p<0.05)$ over the control in terms of hectolitre weight of variety kubsa and Danda'a none of the spray treatments showed significant effect on hectolitre weight of Wane (Table 4). Reduction in test hectolitre weight is largely attributed to reduction in size. With small size more seeds would fit in to given volume. Even though not quantified, [30] who reported pronounced effect of septoria on hectolitre weight and kernel plumpness of some Australian wheat cultivars. However, the effect may vary depending on the variety and location [27].

Seed quality loss

In addition to the yield losses, seeds harvested from fungicide unsprayed plots were shrivelled shape and size that will affect crop establishment of next generation and less plump and low stored food reserve for the next round of crop growth [Figure 1]. The present investigations are in line with the work done by [31-32] who discussed that stripe rust has effect on the end use of an already diminished yield for processing due to the changes in shape and size of the grain.

\section{Conclusion}

In Ethiopia, Arsi, West Arsi and Bale highlands are wheat belt areas covering more than $28 \%$ of wheat production. However, this important staple food crop is found to be affected by a number of fungal diseases that resulted considerable losses in yield. Therefore, the present study aims to contribute towards integrated management of wheat yellow rust for improved yield and physical qualities of bread wheat in Ethiopia. For this purpose, field experiment was conducted during 2017/18 cropping season at yellow rust hotspot areas of Arsi highlands of Ethiopia. Yield and grain weight losses were sever on the wheat varieties kubsa and 
Danda'a and resistant cultivar (Wane) was the best option for disease management. Developing a vigilant disease monitoring system and applying chemicals timely will be important for better crop productivity.

\section{Acknowledgements}

The study was supported by the Ethiopian institute of Agricultural Research and Kulumsa Agricultural Research Center that are providing technical and financial help.

\section{References}

[1] Ayele Badebo. Fehrmann H. and Yahyaoui A. 2008a. Status of wheat stripe rust (Puccinia striiformis) races and their virulence in major wheat growing areas of Ethiopia. Pest Management Journal of Ethiopia, 12: 1-7.

[2] Worku Denbel. 2014. Epidemics of Puccinia striiformis f. sp. tritici in Arsi and West Arsi Zones of Ethiopia in 2010 and identification of effective resistance genes. J. Nat. Sci. Res, 4, pp. 33-39.

[3] Bekele Hundie. Shambel Kumbi and Dereje Hailu. 2002. Seasonal variations in the occurrence of wheat stripe rust in Bale highlands. Pest Management Journal of Ethiopia, 6: 6572 .

[4] Ayele Badebo andWondimu Bayu. 1992. The importance of stripe rust in the major bread wheat producing regions of Ethiopia in 1988-90. In: The 7th Regional Wheat Workshop for Eastern, Central and Southern Africa. Nakuru, Kenya, September 16-19, 1991. CIMMYT. Tanner, D. G. and Mwangi, W. (eds.). pp. 196-202.

[5] Dereje Hailu and Chemeda Fininsa. 2009. Relationship between stripe rust (Puccinia striiformis) and common wheat (Triticum aestivum) yield loss in the highlands of Bale, South Eastern Ethiopia. Archives of Phytopathology and Plant Protection. 42 (6): 508-523.

[6] Habtamu Ayalew, Landuber Wendale, Getaneh Woldeab and Girma Mulugeta, 2016. Yellow rust (Puccinia striiformis) epidemics and yield loss assessment on wheat and triticale in Amhara region, Ethiopia. African Journal of Crop Science. 4 (2): $280-285$.

[7] Dereje Hailu and Chemeda Fininsa. 2007. Epidemics of stripe rust (Puccinia striiformis) on common wheat (Triticum aestivum) in the highlands of Bale, South Eastern Ethiopia. Crop Prot., 26: 1209-1218.

[8] Wanyera R., Njau., Jin Y., Szabo L. J., Rouse M. N., Fetch T., Winnipeg Jr. \& Pretorius Z. A. 2009. Detection of Virulence to Resistance Gene Sr36 within the TTKS Race Lineage of Puccinia graminis f. sp. tritici. American Phytopathological Society. 93 (4): 367-370.

[9] Zhenshng, Kang, et al., 2010. Status of wheat rust research and control in China. BGRI Technical Workshop. 30-31 May. St. Petersburg, Russia.

[10] Birhan Abdulkadir. 2011. KARC Stations distribution and website description.

[11] Peterson R. F. Campbell A. B. and Hannah A. E. 1948. A diagrammatic scale for rust intensity on leaves and stems of cereals. Can J Res. 26: 496-500.

[12] Zadoks J. C. Chang T. T. and Kanzak C. F. 1974. A decimal code for the growth stage of cereals. Weed Research. 14: 415421.

[13] Yadav S. B. \& Bravoco R. R. 1985. A Methodology to model the functional structure of an organization. Computers in Industry. 345-361.

[14] Stubbs RW. Prescott JM. Saari EE. and Dubin H. J. 1986. Cereal diseases methodology manual CIMMYT, Mexico. pp. 46.

[15] Roelfs A. P. Singh R. P Saari E. E. 1992. Rust Diseases of Wheat: Concepts and Methods of Disease Management. CIMMYT, Mexico, D. F. P 81.

[16] Arama, P. F., Parlevliet, J. E., van Silfhout, C. H. 2000. Heading date and resistance to septoria tritici blotch in wheat not genetically associated. Journal of Euphytica Vol. 106, pp. 63-68.

[17] American Association of Cereal Chemistry (AACC). 2000. Approved Methods of the American Association of Cereal Chemists, Inc. State Paul, Minnesota, U.S.A. 1200 pp.

[18] Gomez K. A. and Gomez A. A. 1984. Statistical procedures for agricultural research. John Wiley \& Sons, New York.

[19] SAS (Stastical Analysis Software). 2004. SAS/SAS Institute Inc. Cary, North California. First printing, January 2004. SAS Publishing provides. 513 pp.

[20] Smith R. C. G. Heritage A. D. Stapper M. and Barrs H. D. 1986. Effect of stripe rust (Puccinia striiformis West.) and irrigation on the yield foliage temperature of wheat. Field Crops Research (PaísesBajos). 1986. 14 (1): p. 39-51.

[21] Salman A. Khan M. A. and MumtazHussain. 2006. Prediction of yield losses in wheat varieties/lines due to leaf rust in Faisalabad. Pak. J. Phytopathology. 18 (2): 178-182.

[22] Syed Nadeem Afzal, Haque M. I., Ahmedani M. S., Abdul Rauf, Muhammed Munir, Syeda Siddiqa Firdous, AtiqRehman Rattu and Iftikhar Ahmad, 2008. Impact of Stripe Rust on Kernel Weight of Wheat Varieties sown in Rain fed Areas of Pakistan. Pak. J. Bot., 40 (2): 923-929.

[23] Ahmad S., Afzal M., Noorka I. R., Iqbal Z., Akhtar N., Iftkhar Y. and Kamran M. 2010. Prediction of yield losses in wheat (Triticum aestivumL.) caused by yellow rust in relation to epidemiological factors in Faisalabad. Pak. J. Bot., 42 (1): 401-407.

[24] Eyal Z, Scharen AL, Prescott JM, van Ginkel M. 1987. The Septoria Disease of Wheat: Concepts and methods of disease management. CIMMYT, Mexico.

[25] Goodwin SB, Ben M'Barek S, Dhillon B, Wittenberg AHJ, Crane CF, Hane JK, et al. (2011) Finished Genome of the Fungal Wheat Pathogen Mycosphaerellagraminicola Reveals Dispensome Structure, Chromosome Plasticity, and Stealth Pathogenesis. PLoS Genet 7 (6): e1002070. https://doi.org/10.1371/journal.pgen.1002070Italy. Pp, 1-7.

[26] Abera Takele, Alemu Lencho, Getaneh W/Ab, Endale Hailu, Bekele Kassa, 2015 Status of Wheat Septoria Leaf Blotch (Septaria tritici Roberge in Desmaz) in South West and Western Shewa Zones of Oromiya Regional State, Ethiopia. Research in Plant Sciences. Vol. 3, No. 3, 2015, pp 43-48. 
[27] Dillard HR., Seem RC. 1990. Use of an action threshold for common maize rust to reduce crop loss in sweet corn. Phytopathol. 80: 846-849.

[28] Shafer G. A. and Satorre E. H. 1999. An introduction to physiological-ecological analysis of wheat yield. Wheat Ecology and physiology of yield etermination. Pp 3-12.

[29] Sharma I. 2012. Diseases in Wheat Crops- An Introduction. In: I. Sharma, Ed., and Disease Resistance in Wheat. CABI Plant Protection Series. pp. 1.
[30] Beard C. Jayasena K. Thomas G. and Loughman, R. 2004. Managing stem rust of wheat. Farmnote 73, State of Western Australia.

[31] Boutfirass M. Karrou M. 2003. Optimizing plant population, crop emergence establishment and sowing rate, Explore on farm for adaptation and adopting of GAP for wheat in North Africa, FAO.

[32] O'Brien L. Brown J. Panozzo J. and Archer M. 1990. The effect of stripe rust on the quality of Australian wheat varieties. Aus J Agri Res. 41: 827-833. 